18 回回回回回回回回回回回回回回回回回回回回 Випуск 33

УAK 347.45

Федоров Гиіб Омелянович,

кандилат наук з Аержавного управління, Аоцент кафедри правового забезпечення господарської діяльності Харківського національного університету внутрішніх справ

\title{
ОСОБЛИВОСТІ ЦИВІЛЬНО-ПРАВОВОГО РЕГУЛЮВАННЯ ІНВЕСТИЦІЙНОÏ ДІЯЛЬНОСТІ В УКРАЇНІ
}

Постановка проблеми. ОАним із ключових факторів інвестиційної привабливості як держави загалом, так і окремого регіону $є$ імідж регіону або Аержави. За умови проведення цілої низки політико-адміністративних реформ і визначення вектору розвитку України в напрямі європейської інтеграції значної актуальності набуває питання іміджу держави в аспекті інвестиційної привабливості країни з позицій цивілістичного спрямування. Нині проблема інвестиційного іміАжу України має особливе значення. Незважаючи на проведення останніми роками низки реформ, економіка нашої держави так і не досягла високого рівня розвитку, наша держава не є конкурентоспроможною на міжнародній арені. Отже, позиціонування нашої держави як цікавої та віАкритої Аля міжнародних інвесторів має значно збільшити інвестиційну привабливість віАповіАних елементів економіки країни, що, у свою чергу, вплине позитивно на зростання рівня ведення й умов бізнесу, віАповіАно, на зростання Аобробуту суспільства загалом.

Стан АосліАження теми. Концептуальний ана^із особливостей цивільно-правового регулювання інвестиційної діяльності в Україні був преАметом АосліАження численних учених-правників, економістів, Аержавних управлінців, водночас комплексний аналіз ученими не проводився, що й зумовило науковий інтерес автора.

Унаслідок цього метою статті $€$ АосліАження особливостей цивільно-правового регулювання інвестиційної діяльності в Україні з позицій комп^ексного та всебічного правового аналізу.

ВикиаА основного матеріалу АосліАження з повним обґрунтуванням отриманих наукових результатів. Як віАомо, інвестиційний іміАж Аержави є віАповідним сприйняттям державної еко- номіки та ії інвестиційного клімату керівниками транснаціональних організацій, інвестиційними фондами, міжнародними Аіловими ЗМІ тощо. Тобто інвестиційний іміАж $€$ віАповіАним Аинамічним складником загального бренду Аержави. у перекладі 3 англ. invest означає "вкладати кошти". Тобто інвестиції $€$ віАповіАним укладенням капіталу з метою отримання в подальшому прибутку. Тут варто зупинитися на понятті інвестиційного клімату, оскільки його використано піА час визначення інвестиційного іміАжу Аержави. Інвестиційний клімат $€$ віАповіАним сереАовищем, у якому Аіє певна частина капіталу, а також комплексом віАповідних умов інвестування, Ао якого варто зарахувати соціальні, економічні, політичні, етнічні й інші елементи, а також такі поняття, як нормативно-правове забезпечення тієї чи іншої галузі, трудове законодавство, природні ресурси тощо.

Сьогодні територіальний (Аержавний, регіональний) іміАж $є$ реальним і важливим ресурсом економічної системи. ВіАбувається це через посилення значення інформації Аля забезпечення віАповіАних конкурентних переваг політичних і господарських суб'єктів. Отже, іміАж території, а віАтепер і її репутація в зарубіжних і національних Аілових і суспільно-політичних колах $є$ головними чинниками з питань упроваАження регіональних і загальнодержавних проектів, провіАним конкурентним ресурсом заАля налагодження партнерських віАносин.

Споживачів територіального іміАжу поділяють на три групи: жителі, гості та бізнес. Варто зауважити, що критеріїв до більш детальної Аиференціації ринку "споживачів територіального іміАжу" може бути набагато більше. У кожній групі й у процесі їхньої взаємодії формуються віАповіАні піА- 
групи цільової аудиторії. Зокрема, зрізів і підгруп віАповіАної цільової аудиторії, на які варто орієнтуватися піА час формування та корекції іміджу певної території, як правило, існує досить багато: міжнародні й вітчизняні співтовариства; преАставники органів публічного управління; українські та іноземні покупці; представники вітчизняного й міжнародного бізнесу тощо.

Провідну роль у формуванні іміАжу території відіграють ЗМІ. Значення їх зростає, якщо існує потреба свідомого відтворення або зміни іміджу. Ао того ж штучний іміАж часто не віАтворює, наприклаА, основних економічних і соціальних особливостей, реальних проблем віАповіАної території, принципів ведення бізнесу, що існують у межах віАповіАної аАміністративно-територіальної одиниці, особливостей життя суспільства тощо. І, навпаки, бувають випадки, за яких певна реальна особливість території в перекрученому вигляді може перетворитися на ключову характеристику об'єкта [1].

Аоцільно зауважити, що Ао факторів формування інвестиційної привабливості варто зарахувати сили, що забезпечують формування переваг А^я віАповіАної території в процесі боротьби за обмежене коло інвестиційних ресурсів. У науці існує класичний піАхіА Ао Аиференціації факторів формування інвестиційної привабливості на інституціональні, економічні та соціальні, які існують на мікро- , мезо- й макрорівнях. 3 огляду на мету АосліАження, іміАж Аержави варто визначити до макроекономічного фактору формування інвестиційної привабливості.

В Україні інвестиційна Аіяльність відбувається за участю держави. У нашій державі існує інвестиційне законодавство, яке адаптовано до норм і вимог ЄС. Сьогодні діє більше ніж п'ятдесят міжнародних угоА, преАметом яких є захист інвестиційної Аіяльності та сприяння розвитку такої Аіяльності. А^е зазначені переваги мають зАебільшого теоретичний характер, оскільки на практиці реальну піАтримку інвестиційних проектів із боку органів публічного управління віАчувають зАебільшого керівники вітчизняних піАприємств, інтереси яких лобіюються на вищих рівнях влади.

Маємо зазначити, що сьогодні в межах структур Секретаріату Президента України, Кабінету Міністрів України та Верховної РаАи України піА найменуваннями "прес-служба" функціонують віААіли Й піАрозАіли, що зАійснюють віАповіАні функції зв'язків із громаАськістю. Ці віААіли й піАрозАіли функціонують у структурах віАповіА- них міністерств і відомств, що мають різні найменування: прес-центр, управління інформації та зв'язків із громадськістю, управління з питань внутрішньої політики, прес-служба тощо. Головним завданням Аіяльності вищезазначених піАрозділів зв'язків із громадськістю є формування позитивного іміАжу та сприяння Аоброзичливому ставленню суспільства до новостворених інститутів суспільства. Сама наявність таких структурних одиниць уже вказує на наявність відповіАних позитивних факторів і перспектив у процесі формування позитивного іміАжу держави.

Ще оАним позитивним фактором у процесі формування позитивного іміджу нашої держави $€$ надання інвесторам відповіАних державних гарантій піА час зАійснення ними інвестиційної Аіяльності.

НаприклаА, згіАно зі ст. 397 Господарського кодексу України, Аля забезпечення стабільності правового режиму іноземного інвестування встанов^юються такі гарантії Аля іноземних інвесторів:

- застосування Аержавних гарантій захисту іноземних інвестицій у разі зміни законодавства про іноземні інвестиції;

- гарантії щодо примусового вилучення, а також віА незаконних Аій органів влаАи та їхніх посадових осіб;

- компенсація й відшкодування збитків іноземним інвесторам;

- гарантії в разі припинення інвестиційної Аіяльності;

- гарантії переказу прибутків і використання Аоходів віА іноземних інвестицій;

- інші гарантії здійснення інвестиційної Аіяльності [2].

Ао негативних факторів формування позитивного іміджу держави можна зарахувати збереження сучасних тенденції інвестування лише в ті проекти, котрі приносять швиАкий прибуток. Через те, що ключовим мотивом інвестиційної Аіяльності, як вітчизняної, так й іноземної, $€$ прибуток, вітчизняні інвестори, так само, як й іноземні, не прагнуть інвестувати в розвиток Аержавної економіки, в ії модернізацію або ж у вАосконалення певних управлінських процесів. Тут варто Аодати такий фактор, як високий ризик інвестування внаслідок економічної та політичної нестабільності. Через це будь-який інвестор намагається прискорити процес вивеАення власного прибутку з Аержави. Це позначається на вітчизняних підприємствах, які прагнуть значного наАходження іноземних капіталів і модернізації. 
Отже, спираючись на численні трактування у визначенні інвестиційної привабливості, можемо підкреслити наявність певних загальних ознак. Варто визначати інтегральний показник інвестиційної привабливості за:

- суб'єктивними й об'єктивними умовами інвестування (інтегральні індекси виробничого, трудового, освітнього, фінансового потенціалу);

- перспективами розвитку та рівнем інвестиційної привабливості віАповіАної аАміністративно-територіальної одиниці (Аинамічні показники, такі як природний приріст населення або зростання Аоходу населення);

- Аоцільністю інвестиційних капіталовкладень (показники рівня економічного розвитку, такі як ВНП або загальний експорт/імпорт товарів, показники рівня інвестицій в основний капітал);

- Аотриманням інтересів суб'єкта інвестиційної Аіяльності (показники нормативно-правового забезпечення інвестиційної Аіяльності, споживчого ринку віАповіАної території, креАитного забезпечення або оцінки ризиків).

Як зазначає І. Оніщенко, описовий піАхіА полягає в поверховому аналізі абсолютних показників, Аинаміки та структури ключових показників розвитку віАповіАної аАміністративно-територіальної оАиниці. ЗгіАно із цим піАХоАОМ, експерт самостійно визначає найбільш важливі показники й робить на базі їх висновки стосовно інвестиційного клімату віАповіАної території. ЗАебімьшого зазначений аналіз ґрунтується на вивченні соціально-економічного розвитку віАповіАної території [3, с. 293].

Рейтинговий піАхіА грунтується на опитуванні віАповідних суб'єктів економічної аіяльності певної території, піА час якого визначають віАповіАні напрям впливу та ступінь впливовості певних факторів. Зазначені опитування піАлягають групуванню, і потім за інтегральним показником формується загальний рейтинг території. Зазначену методику широко розповсюАжено на практиці у провідних світових аналітичних і консалтингових агентствах.

У разі використання описового піАходу, оцінка може Аавати віАповіАні змістовні результати, проте це вже перебуває в залежності віА кваліфікації того аналітика, який проводить віАповіАний аналіз. Але зазначена методика потребує віА автора збирання великого обсягу інформації з різноманітних аспектів, її ранжування за рівнем впливу на інвестиційну привабливість. Тут варто зауважити, що отримані піА час застосування описового піАХОАУ результати $€$ Аосить сКмаАними Аля подальшого аналізу.
Отже, проаналізувавши різноманітні піАходи й методики в оцінюванні інвестиційної привабливості території, можна говорити про те, що віА більшості описових методик можна очікувати певний економічний результат. Проте зазначені методи не $€$ уніфікованими та вимагають віА аналітиків збирання й оброблення великої кількості інформації з різних аспектів Аіяльності, їі систематизації за впливом на показники інвестиційної привабливості території. Процес оцінювання в рейтингових методиках більш стандартизований і відрізняється за кількома ознаками. Але результати таких оцінювань не містять галузевого аспекту.

Методики банку та західних агентств позбавлено попередніх недоліків. Вони ґрунтуються на опитуванні сереА тих суб'єктів економічної Аіяльності віАповідної території, Аіяльність яких зазнає характерного за своїми напрямом і ступенем впливу віАповіАних факторів.

Варто зауважити, що рівень активності інвестиційної Аіяльності часто пов'язують із поняттям інвестиційного клімату держави та ії територіальних громаА. Оцінювання інвестиційного клімату $€$ ринковим інструментом оптимізації потоку капіталовкладень.

На нашу Аумку, має Аоцільність АосліАження терміна «інвестиційний кмімат», що визначає певні межі, у яких відбувається інвестиційна Аіяльність. Як наголошує І. Іващук, зазначений термін вкмючає в себе нормативно-правове забезпечення, економічний стан, рівень розвитку продуктивних сил, соціально-економічну стабільність, стан фінансово-кредитної системи, рівень розвитку інвестиційної інфраструктури, валютну й фіскальну політику, інвестиційну активність населення, статус іноземного інвестора та інші фактори [4, с. 72]. Більшість науковців визначають інвестиційний клімат як сукупність економічних, соціальних, політичних і природних передумов, що визначають Аоцільність інвестування госпоАарської системи [5, с. 48]. Фактори, піА впливом яких відбувається формування інвестиційного клімату, зазвичай піАлягають певному кількісному оцінюванню та, віАповіАно, порівняльному аналізу, що визначає рівень інвестиційної привабливості певної аАміністративно-територіальної одиниці порівняно з іншими територіальними об'єАнаннями Аержави [6, с. 17].

НеобхіАною й важливою передумовою у формуванні сприятливого інвестиційного клімату $€$ інвестиційна привабливість регіону. Нині існує велика кількість піАходів до оцінювання інвестиційної привабливості регіонів. Індикатори інвестиційної привабливості неоднакові. Проте варто 
зауважити, що зазначені розробки в розвинених Аержавах є Аосить поширеними. Спеціалізовані наукові центри сьогодні працюють наА розв'язанням таких проблемних ситуацій.

ВіАсутність суттєвого покращання інвестиційного клімату змушує іноземних інвесторів утримуватися віА уходження на український ринок. Погіршення ситуації на світовому ринку робить іноземних інвесторів більш несхильними Ао ризику, концентруючи їхню увагу на якості інвестиційного клімату країни-реципієнта. Хоча високий ступінь відкритості української економіки разом із макроекономічною стабілізацією та прогнозованим з боку Уряду зростанням реального ВВП на 6\% створюють Аля потенційних інвесторів привабливу картину України, саме якість багатьох складників інвестиційного клімату відіграє вирішальну роль у залученні іноземних інвестицій $[7$, с. 41].

Спираючись на висновки за результатами ана^ізу й узагальнення метоАологічних піАХоАів Ао оцінювання інвестиційної привабливості та інвестиційного клімату, вважаємо за доцімьне запропонувати власний структурно-методологічний піАхіА у процесі формування інвестиційного іміАжу віАповіАного територіального об'єкта, що враховував би особливості всіх цільових груп інвесторів. К^ючовим аспектом пропонованого піАходу $€$ наявність можливості коригування іміАжу, внесення змін в іміАжеву програму.

Зазначений піАхіА поділено на три кмючові етапи: піАготовчий етап, етап розроблення й етап реалізації.

На першому, підготовчому, етапі першим кроком $€$ оцінювання іміАжу віАповіАного територіального об'єкта за Аопомогою проведення SWOT-аналізу. Тут виявляються сильні та слабкі сторони, конкурентні переваги й неАоліки та аналізуються внутрішні й зовнішні фактори навколишнього середовища. SWOT-аналіз традиційно розглядається також у теорії таких Аисциплін, як маркетинг, менеджмент та економічний аналіз. SWOT-аналіз - це метоA стратегічного планування, що полягає у виявленні факторів внутрішнього й зовнішнього середовища організації та поділі ï на чотири категорії: Strengths (сильні сторони), Weaknesses (слабкі сторони), Opportunities (можливості) i Threats (загрози) [228]. Сильні (S) і слабкі (W) сторони є факторами внутрішнього середовища об'єкта аналізу. Можливості (0) та загрози (Т) € факторами зовнішнього середовища, тобто тим, що може вплинути на об'єкт ззовні й при цьому не контролюється об'єктом.
Отже, SWOT-аналіз застосовується Ао об'єктів різного масштабу й не тільки в галузях, у яких існує спрямованість на збільшення прибутку, а й у сферах, Ае цілі мають склаАний соціальний чи соціально-економічний характер. У АосліАженні ми спиралися на SWOT-аналіз піА час аналізу інвестиційного потенціалу віАповіАних територіальних об'єктів Аля вАосконалення механізму інвестиційної привабливості щодо залучення іноземних інвестицій в економіку держави.

Аругим кроком на піАготовчому етапі має стати Аіагностика привабливості віАповіАного територіального об'єкта Аля різних цільових груп інвесторів, які, у свою чергу, поділено на внутрішні та зовнішні цільові групи.

Наступним кроком $€$ виявлення проблемних місць стосовно формування іміАжу віАповіАного територіального об'єкта Аля кожної із цільових груп.

Останнім процесом у піаготовчому етапі $€$ залучення Ао розроблення іміАжевої програми зацікавлених і зАатних вплинути на остаточний результат структур, організацій, піАприємств та окремих осіб.

На етапі розроблення ми передусім розробляємо комплекс заходів у межах іміджевої програми, прив'язаних Ао певного періоду часу й забезпечених необхіАними ресурсами.

I на останньому етапі маємо такі три кроки: першим буде реалізація заходів іміАжевої програми; другим є контроль реалізації заходів іміАжевої програми; третім $€$ оцінювання ефективності іміАжевих заходів. НаприклаА, за результатами останнього кроку третього етапу в нас залежно віА отриманих результатів виникає можливість коригування іміАжу, внесення змін Ао іміАжевої програми, що розробляється на Аругому етапі.

ПіА час реалізації будь-якої програми вагомою організаційною умовою щодо залучення інвестицій $€$ формування високого рівня поінформованості й політика віАкритості через інформаційний простір. Варто розробляти Аоктрину інформаційної політики в контексті прагнень Ао розширення поінформованості про інвестиційний потенціал та умови Аля інвесторів. Аля цього потрібно активно використовувати інтернет-простір. Спеціально сформовані сайти для інвесторів мають наАавати повну картину організаційних умов, що використовуються в Аержаві для залучення інвестора. Висвітленню має підяягати АосвіА ефективного інвестування із зазначенням конкретних соціально-економічних зисків, отриманих у результаті вже реалізованих інвестиційних проектів. Окрім того, Аоступним Аля громадськості 
й потенційних інвесторів має бути актуальний перелік інвестиційних пропозицій.

Висновки 3 АосліАження та перспективи подальших розвіАок у цьому напрямі. Отже, оАнією з вагомих організаційних умов Аля залучення інвестицій варто визнати створення інформаційної та консультаційної мереж. Основним

завданням першої буде висвітлення інформації про Аіяльність органів влади з метою підвищення рівня Аовіри й контрольованості її роботи; про можливості розміщення інвестицій і проведення промоції на різних міжнародних заходах - виставках, семінарах, консиліумах, симпозіумах, під час проведення офіційних візитів і зустрічей.

\section{NITEPATYPA:}

1. Важенина И.С. Теоретико-методологические основы определения сущности репутации территории. Екатеринбург: Ин-т экономики УрО РАН, 2006. 326 с.

2. Господарський кодекс України: Закон України від 16 січ. 2003 р. № 436-IV. URL: http://zakon5.rada.gov.ua/laws/show/436-15.

3. Оніщенко I.О. Інвестиційна привабливість України: проблеми та шляхи їх вирішення. Траектория науки: електрон. науч. журн. 2016. № 3 (8). С. 289-295.

4. ващук І.О. Мотиваційні фактори формування інвестиційного клімату регіону. Фінанси Украӥни. 1998. № 1. С. $72-77$.

5. Агеенко А.А. Методологические подходы к оценке инвестиционной привлекательности отраслей экономики региона и отдельных хозяйствующих субъектов. Вопросы статистики. 2003. № 6. С. 48-51.

6. Солдатенков В.В., Федоренко С.В. Аналіз інвестиційного клімату України. Економіка та держава. 2005. № 5. С. 17-20.

7. Данилишин Б.М., Корецький М.Х., Дацій О.І. Інвестиційна політика в Україні: монографія / Рада по вивч. продукт. сил НАН України. Донецьк: Юго-Восток, 2006. 290 с.

\section{Федоров ГАіб Омелянович}

\section{ОСОБЛИВОСТІ ЦИВІАЬНО-ПРАВОВОГО РЕГУЛЮВАННЯ ІНВЕСТИЦІЙНОЇ АІЯАЬНОСТІ В УКРАЇНІ}

Наукова стаття присвячена АосліАженню цивільно-правового регулювання інвестиційній Аіяльності в Україні. У статті на основі комплексного науково-методологічного аналізу й АосліАження різних піАходів учених Ао вказаної проблематики виокремлено власний структурно-методологічний піАхіА у процесі формування інвестиційного іміАжу віАповідного територіального об'єкта, що враховував би особливості всіх цільових груп інвесторів. Ключовим аспектом пропонованого піАходу $€$ наявність можливості коригування іміАжу, внесення змін в іміАжеву програму. Зазначений піАхіА поділено на три ключові етапи: піАготовчий етап, етап розроблення й етап реалізації.

Киючові слова: інвестиційна Аіяльність, цивільно-правове регулювання, Аержавне регулювання, Аержавне управління, іноземні інвестиції.

\section{Федоров Глеб Емельянович}

ОСОБЕННОСТИ ГРАЖААНСКО-ПРАВОВОГО РЕГУЛИРОВАНИЯ ИНВЕСТИЦИОННОЙ АЕЯТЕЛЬНОСТИ В УКРАИНЕ

Научная статья посвящена исследованию гражАанско-правового регулирования инвестиционной Аеятельности в Украине. В статье на основе комплексного научно-методологического анализа и исследования различных поАХОАОв ученых к этой проблематике выАелен собственный структурно-метоАологический поАХОА в процессе формирования инвестиционного имиАжа соответствующего территориального объекта, который учитывал бы особенности всех целевых групп инвесторов. Ключевым аспектом преАлагаемого подхода является наличие возможности корректировки имиАжа, внесение изменений в имиАжевую программу. Указанный подхоА разАелен на три ключевых этапа: подготовительный этап, этап разработки и этап реализации.

Киючевые слова: инвестиционная Аеятельность, гражАанско-правовое регулирование, государственное регумирование, государственное управление, иностранные инвестиции.

\section{Fedorov Gleb}

\section{FEATURES OF CIVIL LEGAL REGULATION OF INVESTMENT ACTIVITY IN UKRAINE}

The scientific article is devoted to the study of civil law regulation of investment activity in Ukraine. It was found out that the factors that make up investment attractiveness are the forces that provide the formation of preferences for the respective territory in the struggle for a limited range of investment resources. In science, there is a classical approach to the differentiation of factors of formation of investment attractiveness for institutional, economic and social, which exist at the micro, meso- and macro levels. Given the purpose of research, the image of the state should be determined by the macroeconomic factor of the formation of investment attractiveness.

In Ukraine, investment activity takes place with the participation of the state. In our country, there is an investment law that has been adapted to EU norms and requirements. To date, there are more than fifty international agreements, the subject of which is the protection of investment activities and the promotion of such activities. But these benefits are mostly theoretical, since in practice, real support for investment projects by public authorities is mostly felt by managers of domestic enterprises whose interests are lobbied at higher levels of government.

It is proved that the investment attractiveness of the region is a necessary and important prerequisite for the formation of a favorable investment climate. There are many approaches to assessing the investment attractiveness 
of the regions. Indicators of investment attractiveness are different. However, it should be noted that these developments in developed countries are quite common. Specialized research centers are currently working on solving such problem situations.

In the article, taking into account the complex scientific and methodological analysis and research of different approaches of scientists in relation to the identified problem, the own structural and methodological approach in the process of forming the investment image of the corresponding territorial object is taken into account, taking into account the features of all target groups of investors. A key aspect of the proposed approach is the possibility of adjusting the image, making changes to the image program. This approach is divided into three key stages: the preparatory stage, the development phase and the implementation phase.

Key words: investment activity, civil law regulation, state regulation, public administration, foreign investments. 